\title{
The water regime of the Monegros playa-lakes as established from ground and satellite data
}

\author{
Carmen Castañeda1, and Juan Herrero \\ Soils and Irrigation Department. C.I.T.A., Government of Aragón \\ P.O. Box 727, 50080 ZARAGOZA, Spain
}

Dr. Juan Herrero Isern

Affiliation and Addres actually: Estación Experimental de Aula Dei (EEAD-CSIC)

Soil and Water Department Avda. Montañana 1005, Zaragoza (Spain)

jhi@eead.csic.es

Dr. Juan Herrero Isern

\begin{abstract}
The Monegros playa-lakes are isolated saline wetlands, locally named "saladas", situated in a vulnerable semi-arid territory where agricultural expansion threatens the natural hydrologic cycle with regular artificial flooding, risking the survival of a valuable natural resource. This study aims to examine the water regime of these playalakesfrom climate data and available hydrologic records. These records are historicaland limited to a series of weekly measurements of depth and of water extent extractedfrom Landsat imagery. We have characterized the hydrological behavior of the playalakesby treating ground and satellite data separately. For this purpose, the playalakesare first grouped according to the water occurrence episodes. Then their hydrologic status is related to the previous rainfall and also to ET0, since there is a lack of local records of wind as well as brine or fresh water evaporation. The northern playa-lakes respond to rain faster than the southern ones. All playa-lakes have a significant relationship between water occurrence and rainfall accumulated within 180 days prior to an observation. A significant relationship between ET0 and water occurrence was found
\end{abstract}


for a shorter 15-day accumulation period. Quantifying the current water regime now is critical for monitoring the effects of expanding irrigation in adjacent lands. Remote sensing is well-suited to an environmental assessment for regions of difficult access with the added benefit of lowered field measurement cost. The hydrological data from the Monegros playa-lakes could be integrated with other playa environments worldwide to compare regionally specific climate conditions.

Keywords: playa-lake, remote sensing, irrigation, flooding regime, Monegros, Spain.

\section{INTRODUCTION}

Playa-lakes represent a small proportion of both modern drylands, about 5\%; (Bryant, 1996) and of sediments within the geological record. Due to the limited knowledge of the processes that occur in these environments, a quantification of contemporary playa hydrology is necessary.

Remote sensing techniques offer rapid acquisition of data with a generally short turn-around time, at a cost lower than that of ground surveys (Hunt et al., 2003), and are a useful tool for delineating the fluctuating margins of shallow-water systems like the playa-lakes. Remote data can also provide an increased historical reach, revealing wetlands hydrology patterns in those cases where the historical data such as water levels is limited (Al-Kudhairy et al., 2002) and allowing us to bring to bear new approaches to field monitoring on old data.

Remotely detecting the varying extent of water bodies in playa-lakes and other wetlands is common for studies of the desertification processes that result from climate and land use changes (Collado et al., 2002). As an example, Schneider et al. (1985) have surveyed the impact of recent climatic changes on the water extent patterns of the Lake 
Chad. Later, Birkett (2000) studied the variations in water depth and the inundation extent of the same lake and its relationships with local and regional precipitation as a means of measuring regional aridity. Harris (1994) correlated the variation of water levels in a lake with precipitation and evaporation as an aid in his climate research. The interaction between hydrological changes observed in Lake Aral and certain regional environmental parameters has been studied by Nakayama et al. (1997). Vázquez et al. (2003) have studied the pattern of observed water surface area in relation with antecedent precipitation as a means for drawing zone maps that indicate flood frequencies.

The playa inundation regime reveals both hydrological and climatic conditions. The influence of climate on the hydrology of Tunisian playas was confirmed by Drake and Bryant (1994) and Bryant and Rainey (2002); the last authors compared current and past information on ephemeral flooding events in these Tunisian playas, and also studied their response to seasonal changes in precipitation and evaporation.

The hydrological changes in playas, due to their high-evaporation/low-rainfall regime, are much more complex than measurements of only the volume/area response can reveal so changes in the timing, frequency and persistence of ephemeral water (Bryant, 1999) need to be studied. Apart from the observations of the wetting-drying cycles, previous hydrological studies have also focused on the annual radiation and windiness (Malek et al., 2002), the evaporation rate (Pike, 1970; Prata, 1990), and the relation between the water surface area and the energy balance (Laymon, 1998) which was then employed in order to assess certain hydrological models.

Although environmental protection policies of European Union blocked irrigation projects in Monegros for several years and contributed to enforce the exclusion of some 
areas from irrigation, the playa-lakes are now being affected by new irrigation infrastructures as well as dumping. A newly operating irrigation project is sure to increase the duration of flood events, their extent, and their frequency, and decrease the salinity of water bodies, all this resulting in the disappearance of valuable habitats. Evidence of the strong impact of irrigation return flows in a salada located in a region close to Monegros is provided by Valero-Garcés et al. (2000).

The analysis of retrospective Landsat TM and ETM+ images and available ground observations is the only way to reconstruct the original water regime of Monegros playa-lakes, i.e., the regime before the irrigation. From this base, it is then possible to establish simple and useful relationships with climate and weather, along with an environmental tool useful to detect any detrimental hydrological alterations the region may suffer as a result of human intervention.

The objective of this study is to identify the water presence-absence cycles in the major Monegros playa-lakes and to establish their hydrological patterns using both ground and satellite data.

\section{STUDY AREA}

The study area lies in the Monegros Desert, in the central area of the Ebro basin (Figure 1), one of the most arid regions of Europe (Herrero and Snyder, 1997). Rainfall is very irregular, with a minimum annual average of $175 \mathrm{~mm}$, a maximum of $535 \mathrm{~mm}$, and an average of $346 \mathrm{~mm}$ for the Petris Weather Station for the period covered by this study, 1985 to 2000. The mean annual $\mathrm{ET}_{0}$ is $1255 \mathrm{~mm}$ based on the estimate of Faci and Martínez-Cob (1991) for the nearby Bujaraloz Weather Station.

Figure 1

Figure 2 
The Monegros playa-lakes fit the genetic and functional description given by Shaw and Thomas (1997) and Brière (2002) for this term. They have been described by several authors, as reviewed by Castañeda (2002), and support endemisms and other organisms of high biogeographical interest, making the Monegros playa-lakes a matter of environmental concern.

These playa-lakes are part of the Bujaraloz-Sástago endorheic complex, with more than a hundred depressions formed in a Miocenic structural platform which is elevated more than $100 \mathrm{~m}$ above the Ebro river water line. Three gypsum-limestone units (lower, intermediate and upper) can be distinguished using the geological map of Salvany et al. (1996) with the gypsum content increasing east to west. Almost all the studied playalakes are part of the intermediate gypsum-limestone unit which contains the most soluble materials.

The platform functions as a single closed basin where the geological features, such as solubility and permeability of materials and its heterogeneous disposition, make the hydrological connections complex. The upper and intermediate units are separated by a thin but laterally continuous lutitic layer segregating the two main aquifers (Figure 2). The upper aquifer contains lutitic limestones with interleaved gypsum layers, and the lower aquifer contains gypsum and limestone with intercalations of lutite. Both aquifers have long water residence periods and furnish salty water to the playa floor (GarcíaVera, 1996).

Monegros playa-lakes are discharge playas (Yechieli and Wood, 2002) though it is possible for the brine, because of its density, to percolate into the groundwater system (Allison and Barnes, 1985). The water table is shallow near the topographic lows of the playa-lakes and the other saline depressions on the platform, allowing water to 
evaporate from the capillary fringe (Samper-Calvete and García-Vera, 1998). Berga (1993) also described the water table as being very close to the surface of the bottom of these depressions, sometimes at less than one meter. Groundwater level rises in winter and falls in spring, in direct response to the rain and the increased evaporation. In the playa-lakes, the water continuously evaporates whether or not there is a free water sheet. The aquifer recharge delay with regard to the rain periods is estimated to be from one to three months.

Monegros playa-lakes play an important role in the regional hydrology, having a close connection with the two main aquifers. Of the playa-lakes included in this study (Figure 2), only Salineta is linked to both aquifers; the remaining playa-lakes (La Playa, Guallar, Piñol, Muerte, Camarón, Rebollón and Rollico) are fed by the lower aquifer and are also interconnected by a groundwater flow moving from NE to SW (Álvarez, 1996). With respect to irrigation, this author detected an insignificantly small rise in groundwater level for this region during 1996. Previous hypothetical estimations carried out by Berga (1993) had estimated that the water extent in some of the playa-lakes would increase due to irrigation by as much as $100 \%$, for dry periods.

\section{DATA}

Almost 100 topographic depressions, locally named saladas, have been inventoried in the platform (Balsa et al, 1991), playa-lakes and other closed saline depressions. Using Landsat imagery, 39 saladas were detected (Castañeda, 2002), some of them are playa-lakes and other are closed saline depressions. Only the eight largest playa-lakes, shown in Figure 2, are included in this study. 
There are three sets of available data on water presence in the Monegros playalakes. The first set contains the monthly ground observations by Berga (1993), taken the first week of each month from January 1987 through September 1990. She identifies water presence or absence for the following 15 playa-lakes: Amarga I, Amarga II, Camarón, Guallar, La Playa, Muerte, Pez, Piñol, Pito, Pueyo, Rebollón, Rollico, Salineta, Saladar and Salobral. These two last playa-lakes have now disappeared due to the irrigation and drainage works, Saladar destroyed by earth filling and drainage ditch excavation, Salobral partially filled with urban debris and the remnant flooded with return flows from the conterminous irrigated land.

The second set, dating from March of 1993 to June of 1997, was compiled by Castañeda (2002). These ground data are weekly observations of water depth measured using a ruler driven into the bed of the following eight playa-lakes: Camarón, Guallar, La Playa, Muerte, Piñol, Rebollón, Rollico and Salineta (Figure 2). The accuracy of the rulers is limited because: (i) the rulers were sunk down into the mud, and some of them had to be reinstalled after disappearing or fallen; (ii) each ruler was put at the deepest point in the playa-lake, as it was inferred in the field, but the wind displaces the sheet of water, as the observers annotated; and (iii) small topographic changes happen in the muddy bottom.

The third data set is a series of water extents detected for each of eight playa-lakes studied by Castañeda (2002) using 26 satellite images taken at different seasons between 1985 and 2000. Two facies related to water presence in the Monegros saladas have been defined by Castañeda et al. (2004): Water (measurable with a ruler), and Watery Ground (not measurable with a ruler but noticeable on the satellite images). The sum of the extent of these two facies, regarded as relevant from the environmental and 
hydrological points of view, is taken to be the total water extent for computations used in this work.

\section{METHODS}

This study includes an examination of water extent itself, and its relationships with weather and other factors.

First we compared monthly data from Berga (1993) with the first observation of each month from Castañeda (2002; 2004) in order to determine the seasonality of the inundations for each playa-lake. Further, we studied separately the water depth measurements and the satellite water extents to obtain (i) the yearly pattern of maximum and minimum water extent, and (ii) the similarity and dissimilarity of the playa-lakes flooding behavior by using a hierarchical cluster analysis.

In the second step, the water data were collated with the rainfall and with the evapotranspiration $\left(\mathrm{ET}_{0}\right)$, those being the main meteorological factors controlling the hydrological status in the playa-lakes. For these analyses, we have included five different periods for calculating the rainfall accumulated as well as the $\mathrm{ET}_{0}$, previous to the water record date : 15, 30, 90, 180 and 365 days.

The rainfall record was taken from the Petris weather station (9552O), located in the area at latitude $41^{\circ} 26^{\prime} 04^{\prime \prime} \mathrm{N}$ and longitude $3^{\circ} 32^{\prime} 32^{\prime \prime} \mathrm{E}$, and at $345 \mathrm{~m}$ elevation above sea level. There are no available wind records or measurements of the saline water evaporation for this area. Thus, the evapotranspiration data were estimated by the Hargreaves method (Allen et al., 1998) using daily temperature data from the Candasnos weather station (9578A) located at latitude $41^{\circ} 30^{\prime} 3^{\prime \prime}$ ' $\mathrm{N}$ and longitude $0^{\circ} 3^{\prime}$ 39' $E$, the closest station maintaining temperature records during the period studied. 
Our calculated $\mathrm{ET}_{0}$ represents the evaporation of well-irrigated grass. Since we have used $\mathrm{ET}_{0}$ for exploratory purposes, we did not apply a conversion coefficient to $\mathrm{ET}_{0}$ to obtain the free saline water sheet $\mathrm{ET}_{0}$. The Hargreaves method was used because of its simplicity and its good monthly estimations of $\mathrm{ET}_{0}$ when compared with lysimetric measurements (Martínez-Cob, personal communication) for our experimental farm located $60 \mathrm{~km}$ away.

In addition to the rainfall and evapotranspiration, we have considered two factors influencing water occurrence: (i) the elevation of the playa-lake bottom above sea level, and (ii) the ratio between the extent of each playa-lake and that of its corresponding basin. For this last measurement we have used the values obtained by Berga (1993), who employed topographic maps of a scale of 1:5000. This author used the visible mark produced by the saline sediment at the bottom of the depression to estimate the bottom extent of each playa-lake.

\section{RESULTS AND DISCUSSION}

\subsection{Water presence variability obtained from ground data.}

Monthly observations from 1987 to 1990 allowed Berga (1993) to distinguish a similar seasonal pattern for Salineta, La Playa, and Guallar, where water is present for more than six months every year (Table 1). Their wet cycle begins in autumn and continues until March.

Using only the first weekly measurement for every month during the period 19931997, Salineta is the only playa-lake with water for more than six months. However, taking into account all the weekly observations (Table 2) the wet cycle of all the saladas lengthens and their response to the spring rains is detected. These data confirm the 
longer wet cycle for Salineta and Guallar found by Berga (1993), the next longest cycles are found for La Playa and Camarón.

Table 1

Table 2

The annual minimum water depth record puts the playa-lakes in two groups: (i) Salineta, La Playa, Guallar, Muerte and Piñol with minimums in 1995; and (ii) Camarón, Rebollón and Rollico, all located in the SW sector of the study area with minimums in 1996. The absolute maximum water depth in this period was $51 \mathrm{~cm}$, recorded for La Playa, 21 December 1994.

Figure 3 shows four distinct distributions of the monthly maximum water depths: (i) Camarón, Rollico, and Rebollón showing synchronous variations; (ii) Piñol, Muerte, and Guallar, also with synchronous variations, but of shorter duration and delayed from the previous group; (iii) La Playa, with the sharpest and highest peaks and a more delayed swell; and finally (iv) Salineta with a great number of fluctuations and the less synchronization with the other playa-lakes.

Figure 3

From the weekly water depths, Salineta, Camarón and La Playa appear as the more wet playa-lakes, and Muerte and Piñol as the driest. The adjusted trend lines show an increase in water depth from 1993 to 1997 for five playa-lakes while Camarón, Piñol and Rebollón are static.

The eight playa-lakes were classified according to their similarity using a cluster analysis based on the simple linkage method, also called "nearest neighbor". The similarity between two playa-lakes $\mathrm{i}$ and $\mathrm{j}$ is given by $\mathrm{s}(\mathrm{i}, \mathrm{j})=100(1-\mathrm{d}(\mathrm{i}, \mathrm{j}) / \mathrm{d}(\mathrm{max})$, where $\mathrm{d}(\max )$ is the maximum distance value in the original matrix of water data. Similarity is higher than $80 \%$ for all them (Figure 4), suggesting a common behavior for 
the studied playa-lakes. The most dissimilar salada is La Playa, followed by Salineta and Guallar. So, from 1993 to 1997 the behavior of these three playa-lakes differs from the pack, which agrees with the results of Berga (1993) for the period 1987 to 1990 . The highest similarity occurs between Rollico and Rebollón, and then between Muerte and Piñol. As reported previously, both these pairs show a parallel evolution of their water depth. The similarities shown by Figure 4 agree with the hydraulic connection established by Álvarez (1996) and previously described.

Figure 4.

A principal component analysis was applied in order to eliminate redundant information, the result being that the three first components have more than the $80 \%$ of the total variance. Table 3 shows the values of the three first components. The first component collects the common terms for all the playa-lakes; the second one enables us to make two groups by their negative and positive values; and the third component isolates La Playa. The result of the cluster analysis applied to the three first components is similar to the result obtained with the original data.

Table 3.

\subsection{Water surface area variability using satellite data.}

Two analyses have been carried out. In the first, the total water surface area for all the 39 playa-lakes is summed for each image date. As expected, and illustrated in Figure 5, this net water extent has a large variability; the highest values are detected in winter and spring. Both the maximum and minimum water area occur in 1987, with the maximum of 402 ha in January and the minimum of 9 ha in August. As a rule, in summer, water extent is lower than 15 ha, with July 1997 (146 ha) and August 1998 (80 ha) being the two exceptions. A rare case emerges for 1999, with more water in August 
than in June in spite of the poor July rainfall $(43 \mathrm{~mm})$ and the intense summer evaporation. It is not possible at this time to determine whether this increase of water occurrence in summer was produced by a water tables rising due to the irrigation of the conterminous lands.

A high variability of water extent from year to year is observed even when comparing years for the same season. Winter water extent, for example, ranges from 100 to 400 ha, spring data fluctuates from 60 ha to more than 340 ha. Summer water extent is more regular, ranging from 19 to 9 except for the rainiest years (1993, 1997, and 1999).

Figure 5.

In the second analysis, the percent of water extent is stated for each of the eight playa-lakes (Figure 6). The Figure shows that this relative water extent ranges from 82.7\% (La Playa) to 56.5\% (Muerte) with its maximum in January 1987. The graphic also shows a consistent evolution for all the playa-lakes except for Salineta, which shows a lower variability and less spiked peaks. Never appearing totally dry, its mean water extent is $50.5 \%$. Usually, the only playa-lake having water in August is Salineta, when the other playa-lakes were dry. Perhaps due to its hydrological connection to the two main aquifers in the area (García Vera, 1996) and to its proximity to the irrigated lands.

Figure 6 .

Figure 7.

Figure 7 shows one more time the great year to year variability of the water extent in winter. The bar graph also reveals the similar behavior of Rollico and Rebollón, and then Camarón, as well as the dissimilarity of Salineta. How all this relates to precedent rain will be examined in the next section. 
Following the same approach used for ground data, we now apply two cluster analyses to the satellite data. First, the eight playa-lakes are clustered by their water extent for each date (Figure 8). Seven saladas have similarity values of over 92\%, and the particularly close relationship of Rollico and Rebollón is again observed; Salineta stands out for its lowest similarity (76\%).

Second, we clustered the dates of the images by their water extent for each playalake, resulting in three groups of dates (Figure 9). Making an analogy with remote sensing studies, here every group represents a "hydrologic signature" similar to the spectral signature, where the playa-lakes correspond to the bands, and the water extent to the digital number. Every hydrological signature depicts a transient status of the saladas constellation. June, July and August are in the first group, with similarity values close to $99 \%$. The second group, with similarity values of $90 \%$, comprises dates from February to August. The third group, with a similarity of $78 \%$ brings wetter dates in January, March, and April. Moreover every group can be related to the water extent in La Playa. For the first, La Playa has less than 10 ha of water while the other playa-lakes are dry, except for Salineta again. For the second La Playa has less than 60 ha of water. The third group includes dates when La Playa hosts more than 70 ha of water. So, it can be said that the greater the water extent for La Playa, the greater the water extent for the rest of the playa-lakes, and simultaneously the less interrelated is the behavior of all the playa-lakes.

The satellite data allows us to group the playa-lakes by their behavior, with a result similar to that of the previous analysis based on the ground records. Salineta is characterized by having water more frequently than the other playa-lakes, which present almost yearly dry periods. The maximum percentage of covered lake-bed in Salineta is 
71\%, though La Playa reaches a maximum of almost $90 \%$. The other studied playalakes can be assembled in two groups. In the first are Rollico, Rebollón and Camarón, with the higher similarity between the two first playa-lakes. Guallar, Muerte and Piñol form the second group. Their geographical distribution and their similar behavior suggest a close groundwater connection, in agreement with the hydrogeological study of Álvarez (1996). A relationship between the aquifers flow directions and these groups of playa-lakes could be established if groundwater dynamics were monitored.

The distinct behaviors of all groups could be related to the lineaments studied by Arlegui et. al. (2000) and to the geological origin of the playa-lakes, as suggested by their shapes. The first group is spread along a mayor axis in NE-SW direction whereas the second is more rounded in shape.

Figure 8.

Figure 9 .

\subsection{Relationship between water depth and rainfall.}

In this section, the water occurrence in the playa-lakes is studied in relation to the rainfall registered at Petris Weather Station. Berga (1993), analyzing the monthly ground data, points out the lack of a clear relationship between water occurrence and rainfall, as water was present during some periods with hydrologic deficit. In order to analyze the weekly ground records for the $1993-1997$ period, the maximum monthly water depth is related to the rainfall of the 30-previous days (Figure 10) as a first approximation. The playa-lakes water extent is directly related to rainfall, and this relation is most obvious when the hydrological year is wetter. When rainfall decreases, the emptying occurs with a delay, as it clearly happens during 1994 in all the playalakes without exception. After the rainfall and in spite of the high evaporation, water 
remains during some months revealing the role of the groundwater as the main regulator of surficial water permanence.

During the most evaporative period, water is prevented from remaining very long despite occasionally persistent rain. This occurs when groundwater level is very low under the playa-lakes bottom. The response of La Playa to rainfall presents a slight delay and remarkable water dissipation in summer, perhaps due to the relatively large evaporative surface of this playa-lake, 200 ha.

Figure 10

We have explored the relationship between water presence and immediately precedent accumulated rain for different accumulation periods. The linear regression between the maximum monthly water depth and the accumulated rain for the previous 15, 30, 90, 180 and 365 days were calculated. We deduce a significant relationship between the water depth and the previous rains, as all the playa-lakes have a significant relation $(\mathrm{P}<0.05)$ with the 90 - and 180-day periods with the strongest relationship for the 180 -day period. In the best cases the $50 \%$ of the variance of the water depth data can be explained by the variations of the accumulated rainfall in the 180 previous days.

The determination coefficients $\left(r^{2}\right)$ in Figure 11 show that the northeastern playalakes are most strongly related to their 90-day accumulated rain, whereas the southwestern playa-lakes are most strongly related to the 180-day period. The other playa-lakes are positioned in the middle, both geographically and for their estimated $\mathrm{r}^{2}$. Thus, the rain response is faster for the northern playa-lakes and slows as a southwestern path is traced. This geographical variation agrees with the hydraulic connection established by Álvarez (1996) and suggests once more their regulation by groundwater. 


\subsection{Relationship between water surface area and rainfall.}

The relationships between the water surface area as detected by remote sensing and the accumulated rainfall were analyzed for periods of 30, 90, 180 and 365 days previous to the image date. The eight playa-lakes show one significant relationship $(\mathrm{P}<$ 0.05) for the 180 day accumulated rainfall period. In the most favorable of cases, only $30 \%$ of the water surface area variation can be explained by the rainfall variation for the previous 180 days. Salineta is an exception, having no significant relation with any analyzed rain period.

Water surface area and depth share a significant $(\mathrm{P}<0.05)$ relationship with the previous 180 days of rainfall. The $r^{2}$ between accumulated rainfall and water surface area was lower than that for accumulated rainfall and water depth. This is attributed to the different kind of data sets used. First, the water surface areas are a long set of sparse records, much less frequent than the water depth records. Second, the water surface data includes Watery Ground, surfaces not measurable with a ruler but noticeable on the satellite images. This last component is most likely the main culprit for the attenuation of the $\mathrm{r}^{2}$ values.

\subsection{Relationship between water depth and evaporation.}

Severe evaporation is a key factor influencing the presence of water in the playalakes, better said, in the emptying of water from the lakes. The $r^{2}$ values of the linear regression between the maximum monthly depth and the accumulated $\mathrm{ET}_{0}$ for the 15 , 30, 90, 180 and 365 previous days. All the playa-lakes have a significant relationship (P $<0.05$ ) with the 15-, 30- and 90-day period of accumulated $\mathrm{ET}_{0}$. And all the playa-lakes have their maximum $\mathrm{r}^{2}$ for the 15-day period. 
We have evaluated the effect of the extent of the bottom surface of each playalake, since lake size should condition the evaporation rate, but no relationship with $\mathrm{r}^{2}$ variation was found.

\subsection{Relationship between water surface area and evaporation.}

The regressions of water surface areas on the accumulated $\mathrm{ET}_{0}$ for the same five accumulation periods yield $\mathrm{r}^{2}$ values that decrease as the period of accumulated $\mathrm{ET}_{0}$ increases. The best relationships occur for $\mathrm{ET}_{0}(15)$ and give $\mathrm{r}^{2}$ values between $40 \%$ and $50 \%$. Salineta is an exception, with significant relationships only for the long periods of 90 and 180 days.

A significant relationship between $\mathrm{ET}_{0}$ and water surface area was found: the shorter the accumulation period the stronger the relationship. Salineta is again an exception, showing the strongest relationship for the $\mathrm{ET}_{0}(180)$. For the most favorable cases, $50 \%$ of the water surface area variation can be explained by $\mathrm{ET}_{0}$ variations. Surface area variations have a tighter relationship to $\mathrm{ET}_{0}$ variations than do water depth variations.

In summary, $\mathrm{ET}_{0}$ is similarly related both water surface areas and the water depth, with $\mathrm{r}^{2}$ values increasing as the previous period of computed $\mathrm{ET}_{0}$ decreases. For the 15day period, the maximum $\mathrm{r}^{2}$ is $40 \%$ for water depth and $50 \%$ for water surface area. Salineta is the exception, with stronger relationships for the longer periods. Those disparities can be attributed to (i) a difference in the amount of water computed from the two sources of water data, satellite and ruler, as in previous sections; (ii) the use of Hargreaves $\mathrm{ET}_{0}$ as surrogate for the real ET. Hargreaves' estimate, for example, does 
not account for the salinity of the water or the permanently humid bottom where evaporation continues even after the water sheet has disappeared.

\subsection{Other factors}

Two additional factors supposedly influence water presence - absence and the length of the playa-lake humid cycles: (i) the elevation of the playa-lake bottom, since this should be connected to groundwater level, and (ii) the ratio between the area of each playa-lake and its basin extent, since it could be related to the runoff.

In Figure 12 the water occurrence is computed as the percent of watery weeks during the period 1993-1997. This number is then plotted against the elevation and the latitude of the eight playa-lakes. Though there appears to be no direct relationship between elevation and water occurrence, playa-lakes can still be grouped as in previous sections. Rebollón and Rollico, with the lowest elevation, have a higher water occurrence than Guallar, Muerte and Piñol, which are more elevated. Salineta continues as the oddball, wetter than the other playa-lakes while situated at a medium elevation in the platform.

\section{Figure 12}

The second factor examined was the ratio between the basin area and the bottom extent of each playa-lake, defined by $\rho$, as shown in Table 4. During the period 19871991, there was no significant relation between $\rho$ and the water occurrence of each playa-lake (Berga, 1993). During the period 1993-1997 it is also observed that the size of the playa-lakes does not influence the water occurrence. Judging by their $\rho$ value, La Playa and Rebollón seem to be collecting significant runoff seeing as their basin area is five times their bottom extent. But both playa-lakes have a medium wet period (42\%) similar to Guallar which has a low ratio. Salineta continues as the Lone Ranger Playa- 
lake, for its small size, for having the smallest $\rho$ values, and as the playa-lake with the largest wet period. From among the smallest of the studied playa-lakes ( $<18$ ha), Piñol and Muerte have similar water occurrence and similar $\rho$ values to Salineta.

Table 4.

\subsection{Future uses of our study}

The flood regime of the Monegros playa-lakes has been described in relation to the climatic and hydrogeological features of the basin. The irrigation of the conterminous lands threatens the playa-lakes with artificial over-flooding and a drastic alteration of the brine composition. For this reason it is urgent to document the natural baseline of the hydrological regime so as to be able to detect undesirable environmental effects such as a rising water table or soil salinization.

A sufficiently prolonged study of the natural regime of these playa-lakes together with the available climatic series analysis should allow us to uncover any parallelism that there may be with the evolution of Lake Gallocanta, the largest endorheic lake in the Ebro basin, where Rodó et al. (1977) have demonstrated a close relationship between the variations of standing water and climatic oscillations of the North Atlantic. The comparison could be extended to similar environments studied by other authors, for similar bodies such as Lake Chad or the Tunisian playas of northern Africa, though differences in their dry and wet seasons from those of Spanish playa-lakes, would have to be taken into account. And unlike their African cousins, the variations of the Spanish playa-lakes (< 200 ha), are difficult to detect with sensors of low spatial resolution and high sampling frequency, as are used in monitoring the African playas. 


\section{CONCLUSIONS}

The water presence-absence cycles in the major Monegros playa-lakes have been identified using ground observations and satellite data. Both data sources agree, allowing us to group the playa-lakes according to their common inundation patterns. There is a close relationship between each of these groups and their location on hydrogeological units established by other authors.

The first group comprises the southwestern playa-lakes, Rollico, Rebollón and Camarón, with a higher similarity between the first two. The second group unites Guallar, Muerte and Piñol, and lies in the middle of the platform. Salineta, in the north, is in a class by itself with more water occurrence than the other playa-lakes. La Playa, also a singleton, stands out as the largest in size and has an intermediate behavior between Salineta and the second group. The water extent in La Playa has been found to be an indicator of the general water status of the playa-lakes during the period studied.

The relationship between the water occurrence and both the previous rainfall and $\mathrm{ET}_{0}$ is confirmed. Up to $50 \%$ of the variance of the water depth can be explained by the variations of the accumulated rainfall for the 180 days previous to the water presence measurements, and this relationship decreases as a path is followed in a southwesterly direction, from Salineta to Rebollón. Precedent rainfall is a better predictor of playalake water surface areas than of lake depth, though the former relationship occasionally reaches the highest $\mathrm{r}^{2}$ values.

A significant relationship between $\mathrm{ET}_{0}$ and water occurrence was found, being the relationship tightest for the shorter accumulation period. Up to $40 \%$ of the variance of the water depth data can be explained by variations in the 15-day accumulated $\mathrm{ET}_{0}$. Similarly, $50 \%$ of the variation of the water surface area can be explained by the same 
$\mathrm{ET}_{0}$ variations. Salineta is again an exception, showing the strongest relationship for the180 day $\mathrm{ET}_{0}$.

Water depth and water extent respond differently to accumulated rainfall and $\mathrm{ET}_{0}$. These differences are attributable to the different frequency and time span covered by each data set. Water depth and surface extent are distinct but equally useful scales of observation, more synoptic for the last.

The relationships between the water occurrence and the playa-lake elevation confirm the previous groups. The potential runoff from the playa-lake basins does not play a role in water persistence.

Remote sensing has yielded excellent synoptic information and quantitative data on water occurrence and the hydrologic behavior of the Monegros playa-lakes. Given the lack of ground observations before 1993 and after 1997, the use of remote data becomes necessary in the monitoring of hydrologic processes, and environmental conditions. As an extension of this study, the evolution data of these playa-lakes could be integrated with that of other playa environments for regional or worldwide climatic studies.

Our full empirical approach to hydrologic behavior is a straightforward way to make good use of limited available observations and to design effective monitoring schemes until such time as soil hydrology, brine evaporation and other as yet unavailable field information can be applied to construct a mechanistic hydrological model.

Our study confirms the role of the aquifers in the hydrological cycle of these arid wetlands although the monitoring of the groundwater levels is necessary to quantify the relationship. This groundwater connection with the playa-lakes and their water budget 
are modeled in a forthcoming article. The increasing of the saline water table by the future irrigation flows threatens these habitats, by changing their ephemeral saline sheet

of water into a permanent non saline and contaminated water. Our full empirical approach to hydrologic behavior is a straightforward way to make good use of limited available observations and to provide important information on the changing hydrology of these playa-lakes and on their natural state prior to the anthropogenic activity.

\section{ACKNOWLEDGEMENTS}

This work is funded by the Government of Aragón within the ARGOS research project, in the framework of the Comisión de Trabajo de los Pirineos. It is a part of the preliminary study of the project INTAS-1069. Thanks to Dr. R.G. Bryant and to other unknown reviewer for their comments and suggestions. 


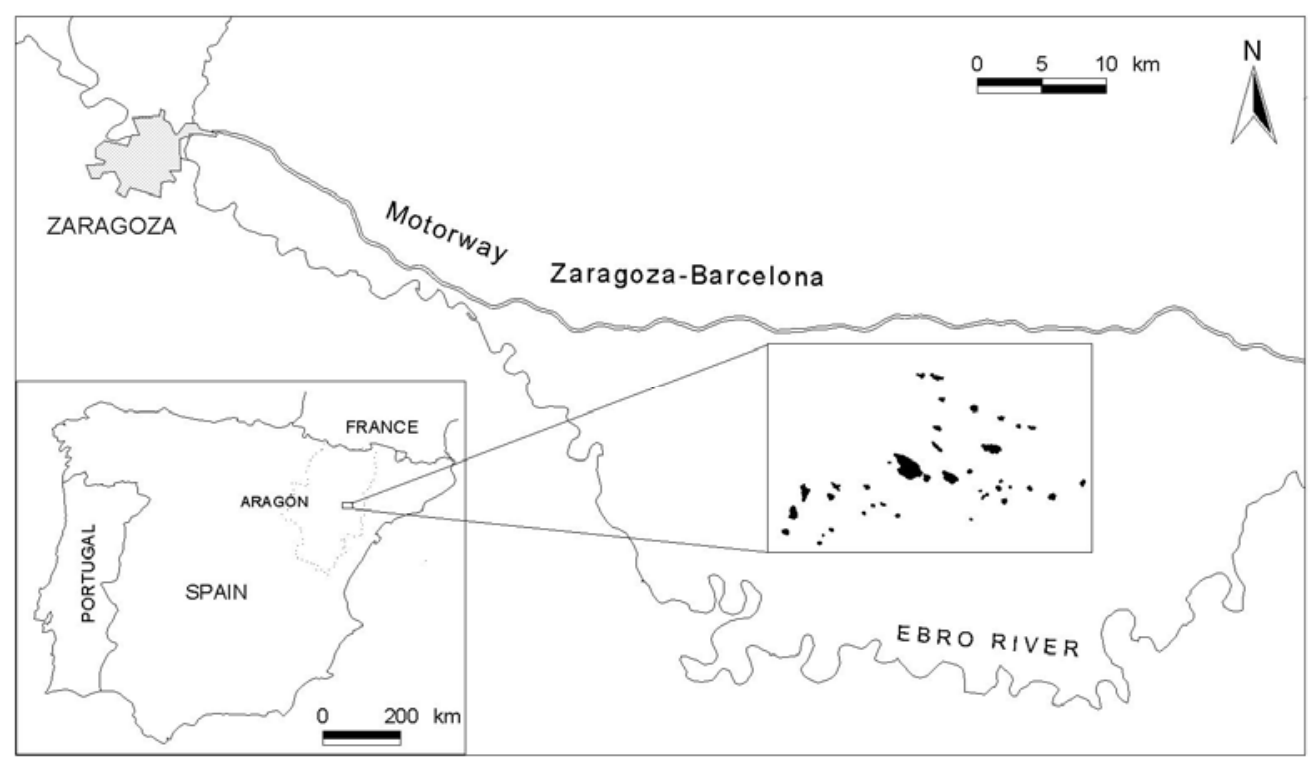

Figure 1

Miocenic aquifers and studied playa-lakes

$\checkmark$ Upper aquifer (upper gypsum-limestone unit)

Lower aquifer (intermediate gysum-limestone unit)

Playa-lakes

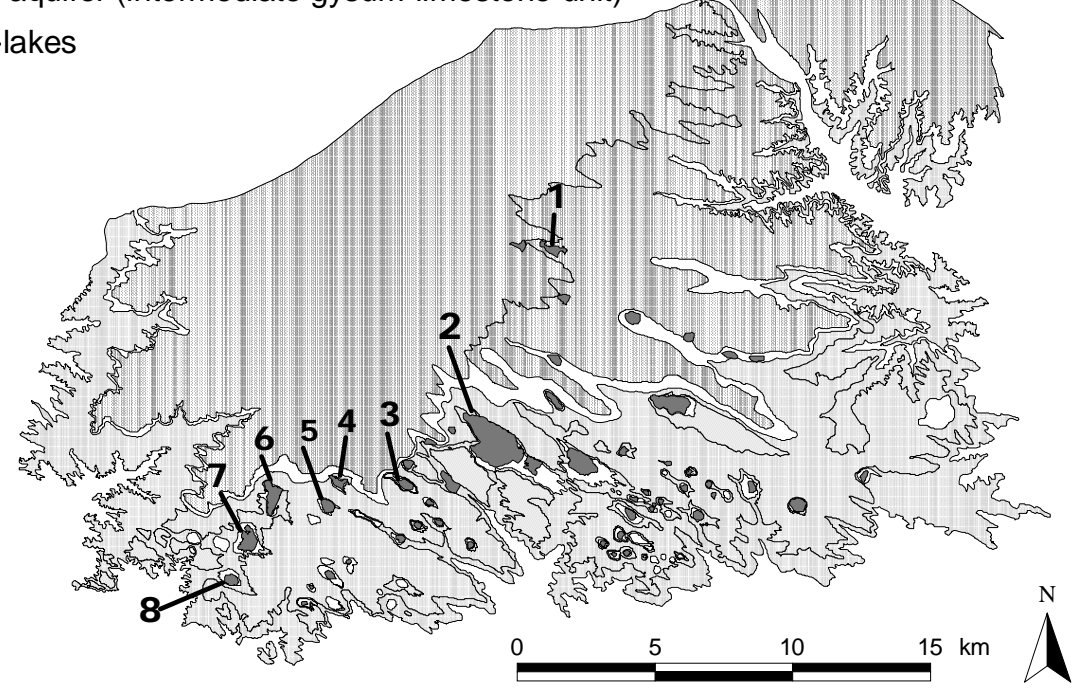

Studied playa-lakes: 1: Salineta; 2: La Playa; 3: Guallar; 4: Piñol; 5: Muerte; 6: Camarón; 7: Rollico; 8: Rebollón.

Figure 2 


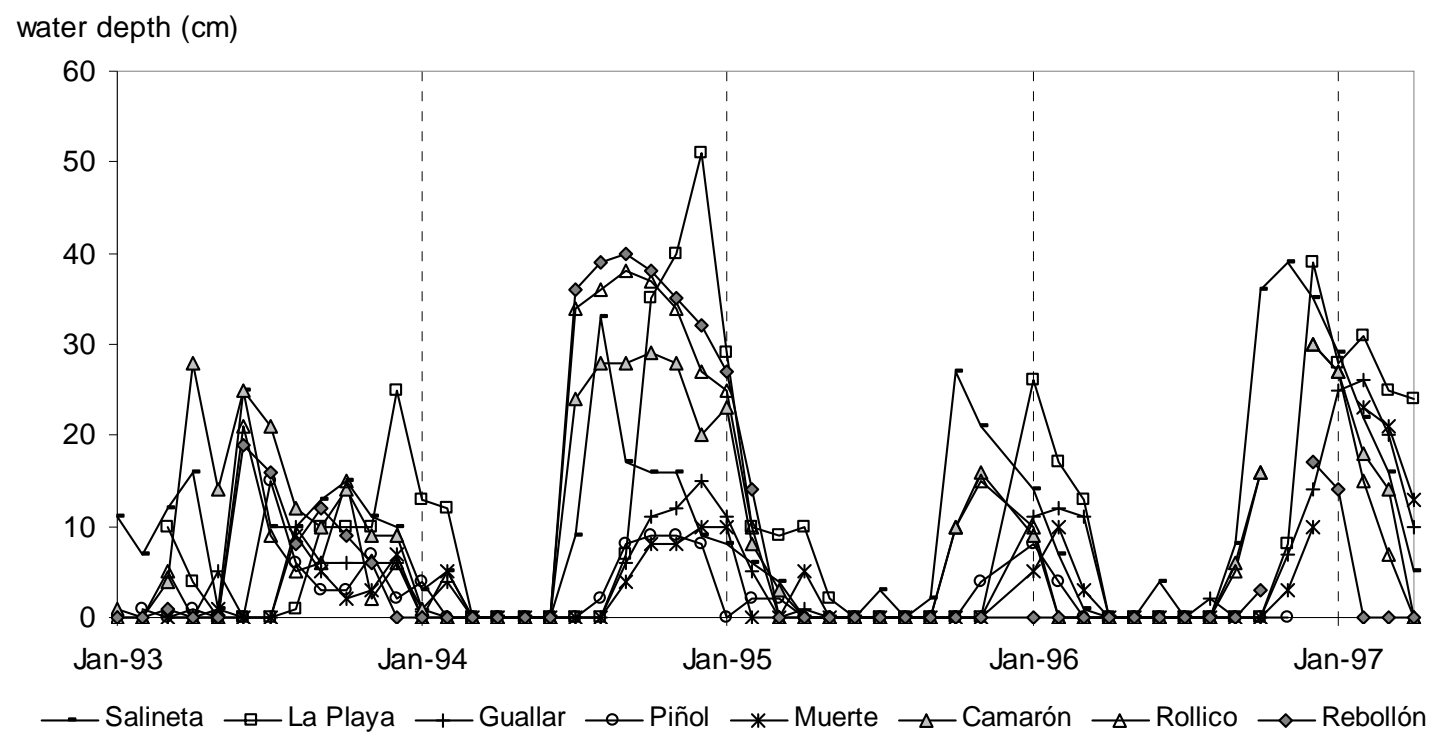

Figure 3

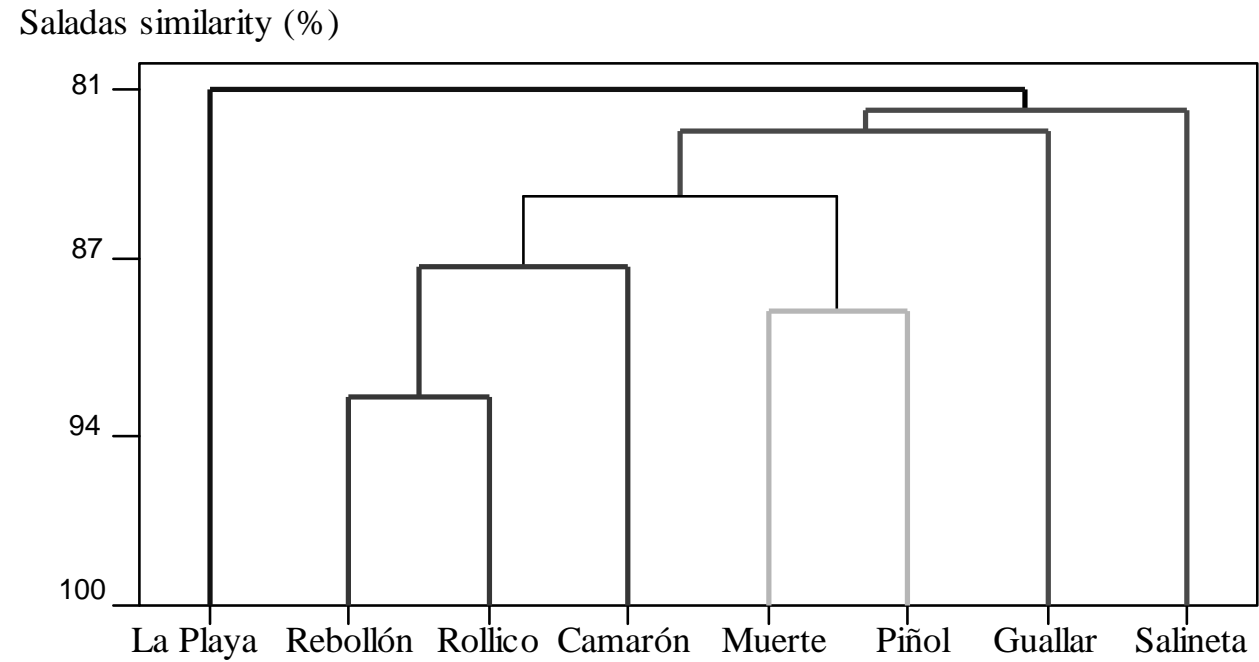

Figure 4 
Total water (ha)

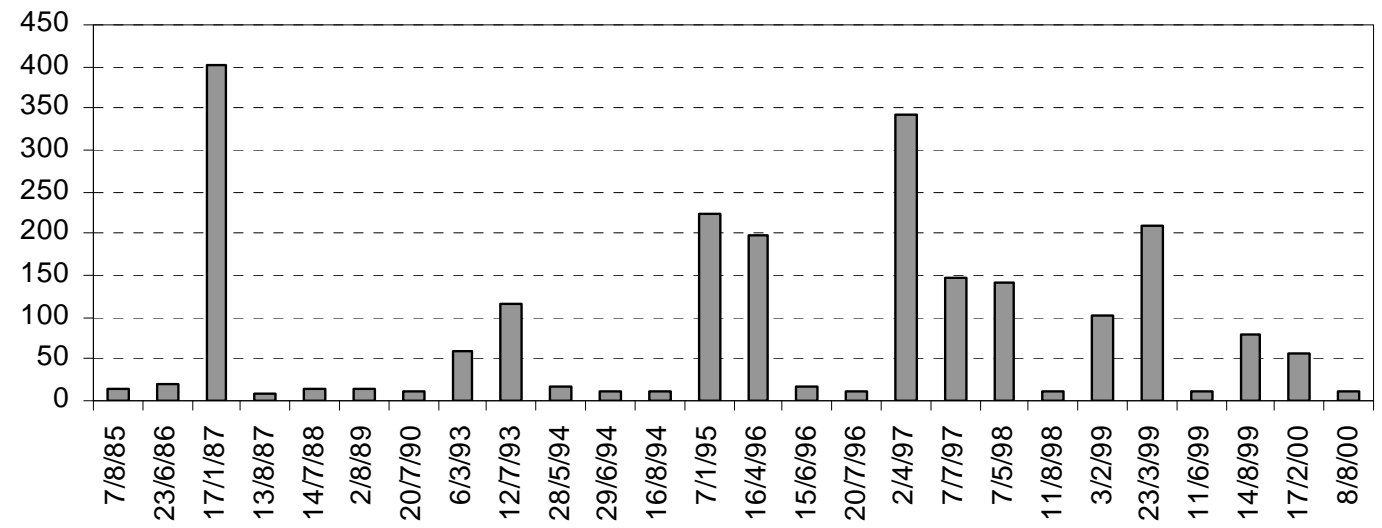

Figure 5

percentage of the playa-
lake bottom covered by

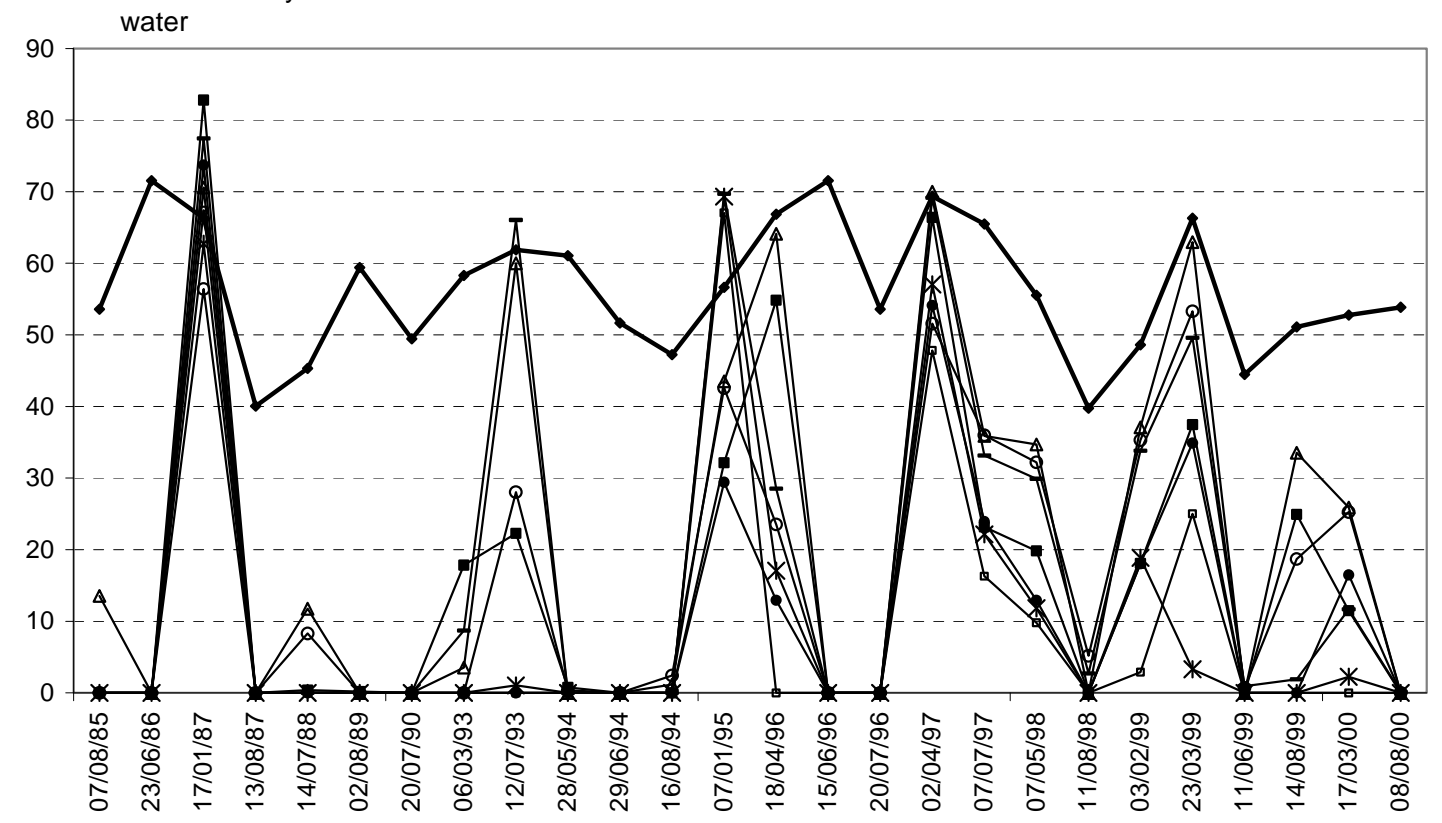

$\rightarrow$ Salineta $\rightarrow$ La Playa $\triangle$ Guallar $\rightarrow$ Piñol $\rightarrow$ Muerte - Camarón $\rightarrow$ Rollico $\rightarrow$ Rebollon

Figure 6. 


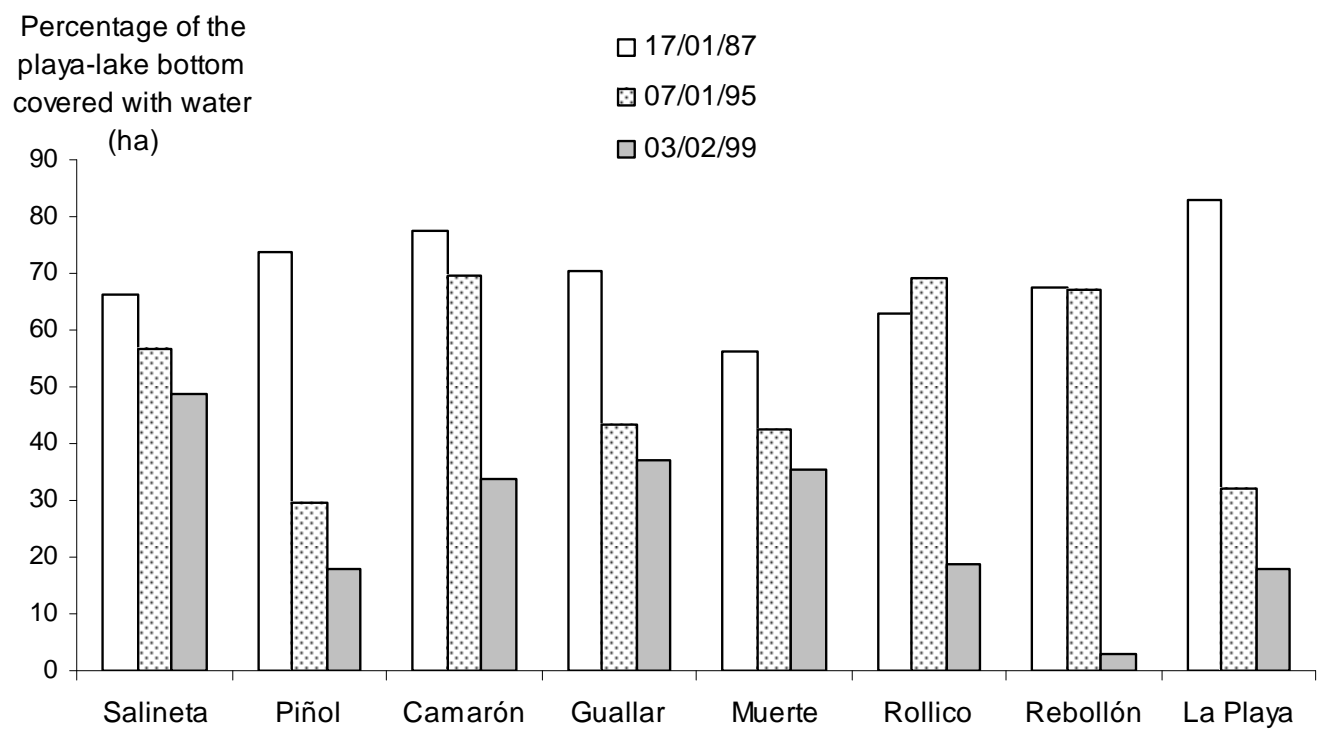

Figure 7

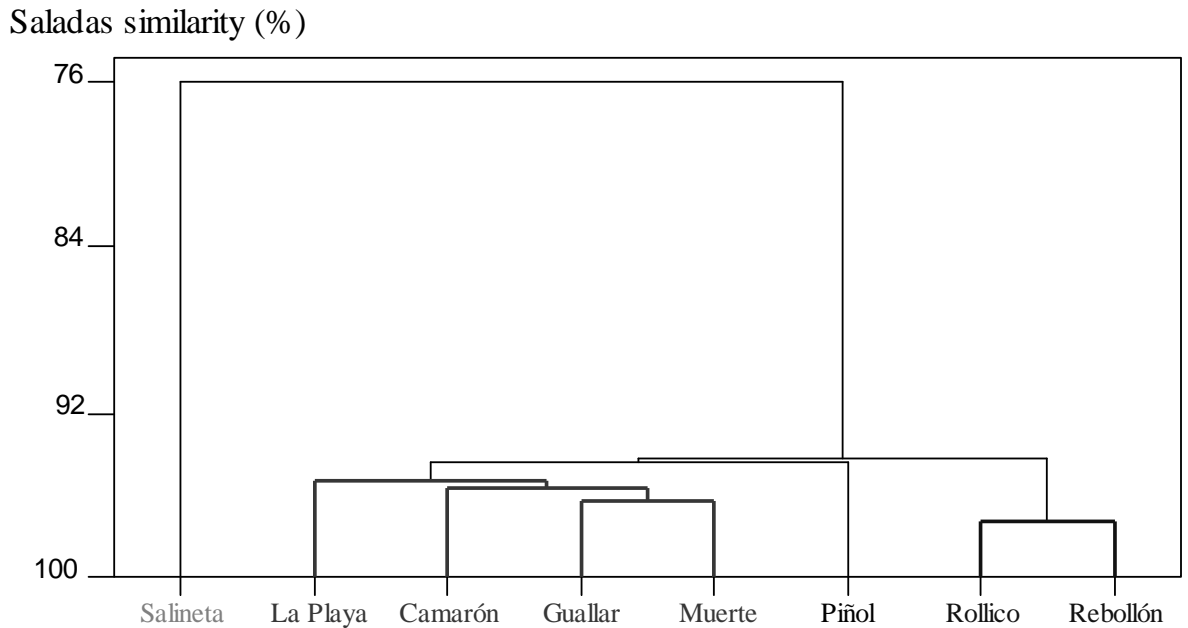

Figure 8 
similarity (\%)

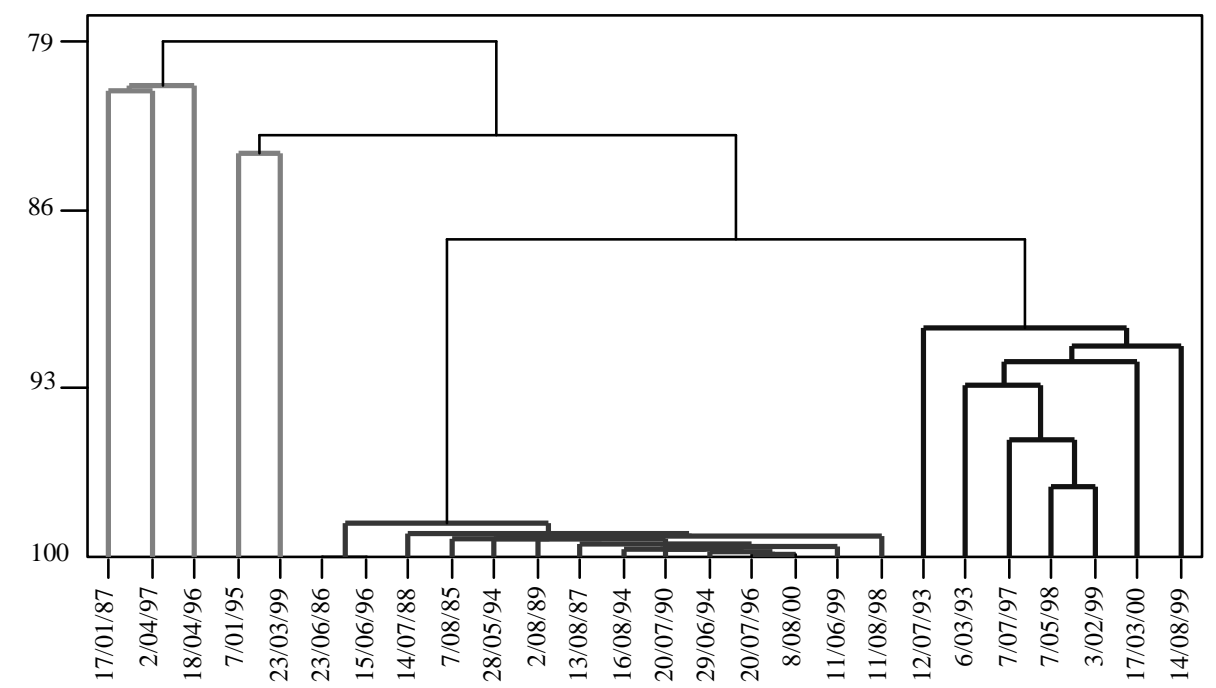

Figure 9

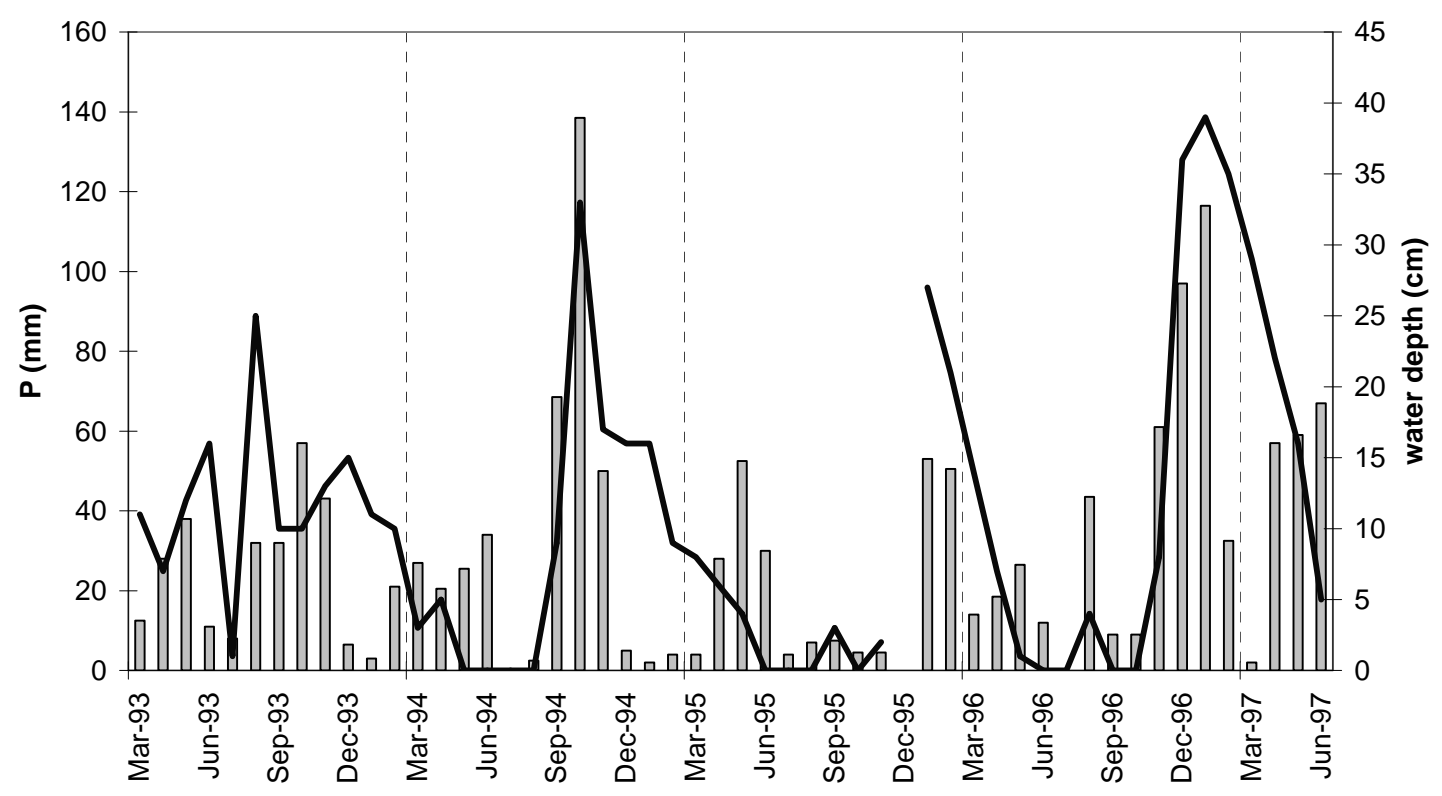

Figure 10 


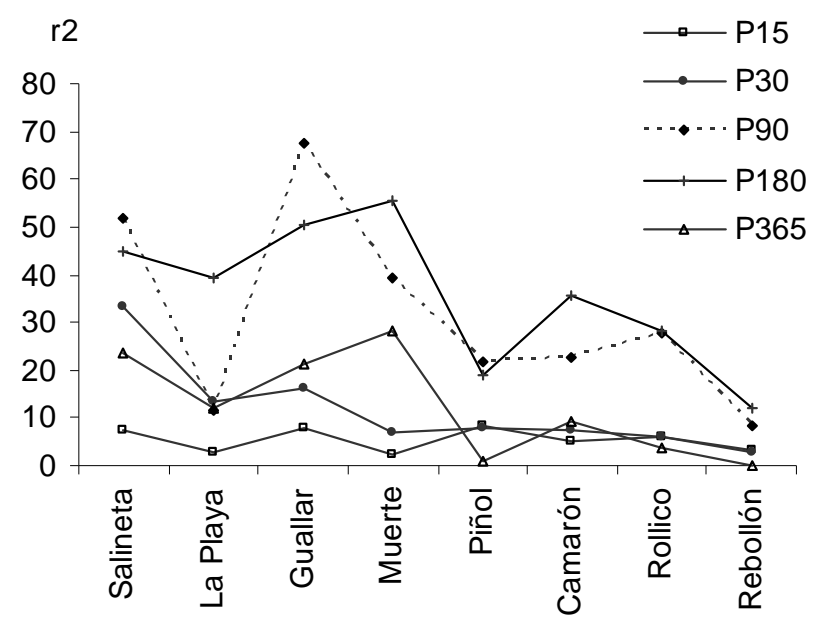

Figure 11
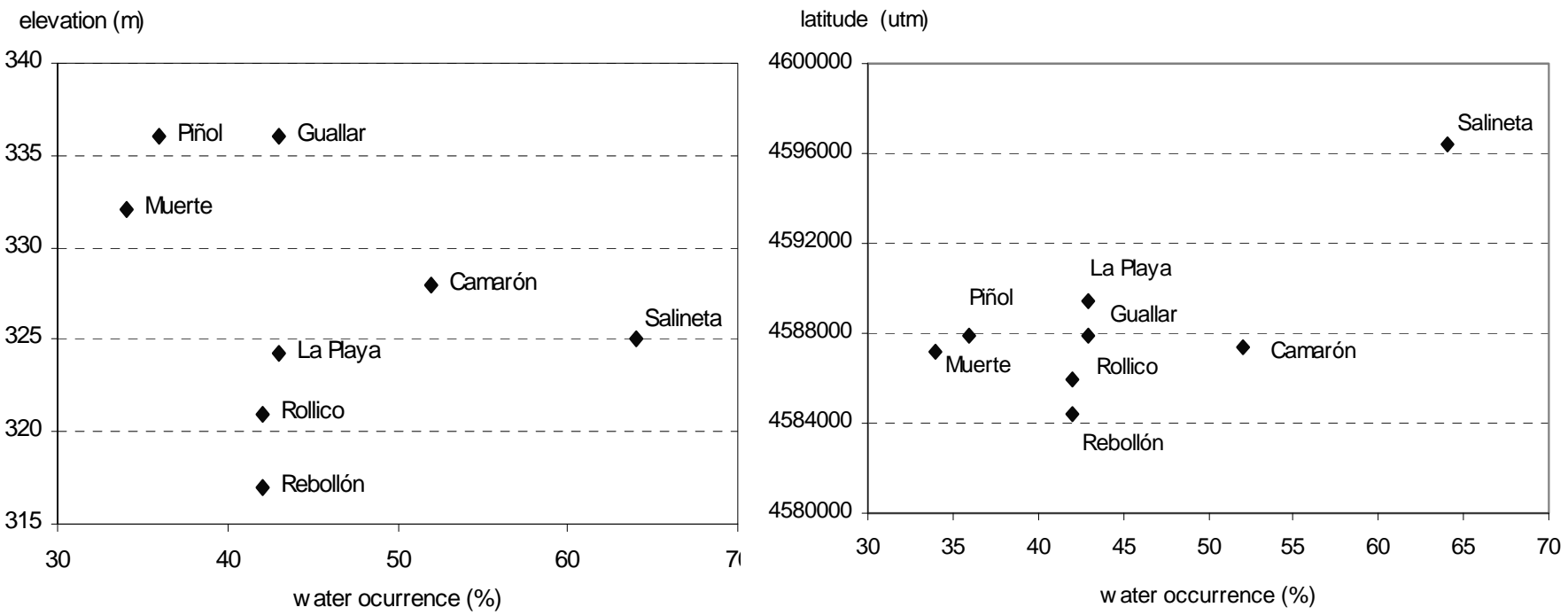

Figure 12 
Table 1

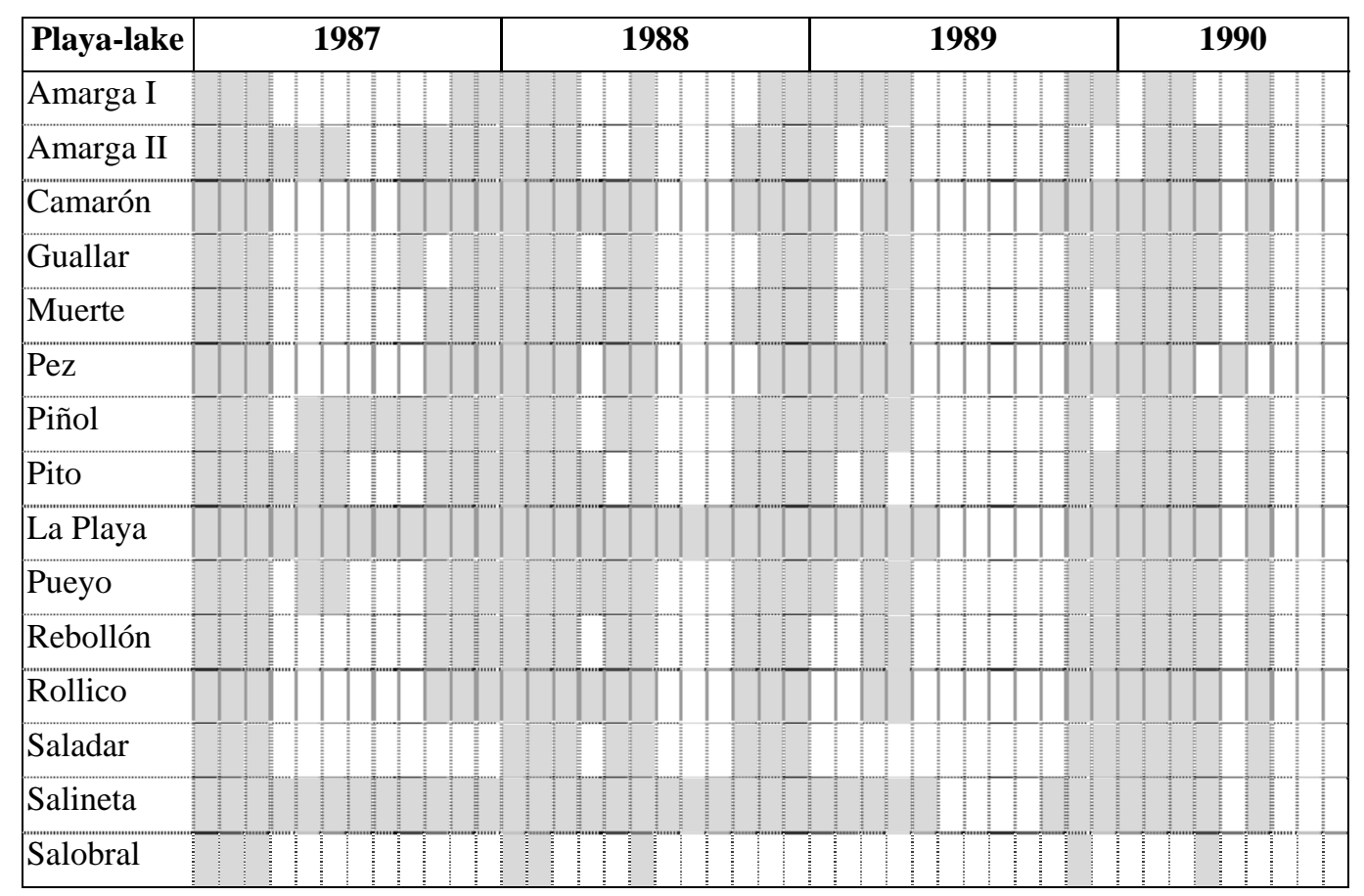

Table 2

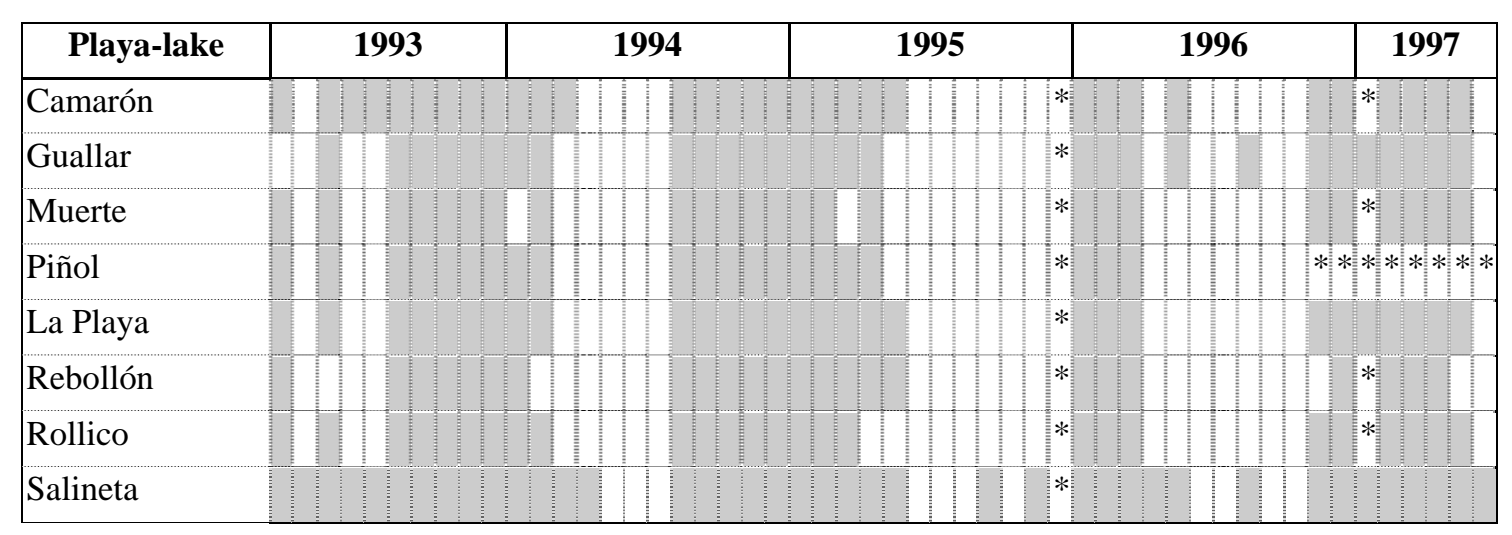


Table 3

\begin{tabular}{cccc}
\hline Playa-lake & CP1 & CP2 & CP3 \\
\hline Salineta & -0.790 & 0.268 & 0.197 \\
La Playa & -0.775 & -0.107 & 0.425 \\
Guallar & -0.754 & 0.358 & 0.341 \\
Muerte & -0.803 & 0.274 & -0.367 \\
Piñol & -0.845 & 0.315 & -0.242 \\
Camarón & -0.840 & -0.187 & -0.260 \\
Rollico & -0.877 & -0.334 & -0.059 \\
Rebollón & -0.780 & -0.556 & 0.059 \\
\hline
\end{tabular}

Table 4

\begin{tabular}{ccccc}
\hline Playa-lake & $\begin{array}{c}(\mathbf{1}) \\
\text { Playa-lake bottom } \\
\text { extent (ha) }\end{array}$ & $\begin{array}{c}\mathbf{( 2 )} \\
\text { Playa-lake basin } \\
\text { area (ha) }\end{array}$ & $\begin{array}{c}\boldsymbol{\rho} \\
\mathbf{( 2 )} / \mathbf{( 1 )}\end{array}$ & $\begin{array}{c}\text { Water } \\
\text { occurrence (\%) }\end{array}$ \\
\hline Salineta & 15.0 & 27.5 & 1.83 & 64 \\
La Playa & 190.0 & 2052.0 & 10.80 & 43 \\
Guallar & 15.0 & 32.5 & 2.17 & 43 \\
Piñol & 15.0 & 32.5 & 2.17 & 36 \\
Muerte & 17.5 & 27.5 & 2.19 & 34 \\
Camarón & 37.5 & 72.5 & 1.93 & 52 \\
Rollico & 30.0 & 85.0 & 2.83 & 42 \\
Rebollón & 12.5 & 90.0 & 7.20 & 42 \\
\hline
\end{tabular}




\section{Figure captions}

Figure 1. Location of the studied playa-lakes digitized from Landsat imagery.

Figure 2. The studied playa-lakes and the two main aquifers in the platform. These aquifers are related to the Miocenic gypsum-limestone units described by GarcíaVera (1996).

Figure 3. Monthly maximum values of water depth for the eight playa-lakes.

Figure 4. Similarity of the playa-lakes based in the weekly measurements of their water depth from 1993 to 1997.

Figure 5. Total water surface area detected in Landsat imagery in every date.

Figure 6. Percentage of the playa-lake bottom covered by water.

Figure 10. Percentage of the playa-lake bottom covered by water, for the winter months.

Figure 8. Similarity of the playa-lakes according with their water surface area detected using 26 Landsat images.

Figure 9. Similarity between the dates of the images analyzed according to the water surface area of the eight playa-lakes.

Figure 10. An example of the maximum monthly water depth plotted together with the rainfall of the previous 30 days, for Salineta playa-lake.

Figure 11. Determination coefficients $\left(\mathrm{r}^{2}\right)$ between the maximum monthly water depth and the accumulated rain for the 15, 30, 90, 180 and 365 days previous to the depth measurement.

Figure 12. Water occurrence in terms of percentage of watery weeks plotted against elevation and latitude. 


\section{Table captions}

Table 1. Months with water presence (grey) and absence (white) according to Berga (1993).

Table 2. Months with water presence (grey) and absence (white) according to Dirección General de Medio Natural observations (Castañeda, 2002). *: O data.

Table 3. Values of the first three principal components obtained from the weekly water depth measurements in the eight playa-lakes.

Table 4. The bottom extent (ha) of the eight playa-lakes and their basin area estimated by Berga (1993). $\rho$ : ratio between the basin area and the playa-lake bottom extent area. 


\section{REFERENCES}

Al-Khudhairy, D.H.A., Leemhuis, C., Hoffmann, V. Shepherd, I.M. Calaon, R., Thompson, J.R., Gavin, H., Gasca-Tucker, D.L., Zalidis, G., Bilas, G. and Papadimos, D., 2002. Monitoring wetland dicht water levels using Landsat TM and ground-based measurements. Photogrammetric Engineering and Remote Sensing 68(8): 809-818.

Allen, R.G., Pereira, L.S., Raes, D. and Smith, M., 1998. Crop evapotranspiration: guidelines for computing crop water requirements. FAO Irrigation and Drainage Paper 56. FAO, Roma, Italia. 300 pp.

Allison, G.B. and Barnes, C.J., 1985. Estimation of evaporation from the normally “dry” Lake Frome in South Australia. Journal of Hydrology 78(3-4): 229-242.

Álvarez Chaín, M., 1996. Estudio hidrogeológico complementario de los sectores VII, IX, XI y ampliación a los sectores X y XII de la zona regable de los Monegros II (Zaragoza y Huesca). Informe final, Tomo I-Memoria. Ministerio de Agricultura, Pesca y Alimentación. Dirección General de Planificación y Desarrollo Rural. Madrid, $102+19$ pp.

Arlegui, L.E. and Soriano, M.A., 2003. An example of a comparison between Thematic Mapper and radar images in the central Ebro basin. International Journal of Remote Sensing 24(3): 457-474.

Balsa, J., Guerrero, C., Pascual, M.L. and Montes, C., 1991. Las saladas de BujaralozSástago y las saladas de Chiprana: riqueza natural de Aragón. Empelte, 7. Grupo Cultural Caspolino. Caspe, Zaragoza.

Berga, A., 1993. Relaciones clima-agua-suelo-subsuelo en Monegros II. PhD Thesis, Universidad de Lérida, Spain, pp.392 + annexes. 
Birkett, C.M., 2000. Synergistic remote sensing of Lake Chad: variability of basin inundation. Remote Sensing of Environment 72: 218-236.

Brière, P.R., 2000. Playa, playa lake, sabkha: Proposed definitions for old terms. Journal of Arid Environments 45(1): 1-7.

Bryant, R.G., 1996. Validated linear mixture modelling of Landsat TM data for mapping evaporite minerals on a playa surface: methods and applications. International Journal of Remote Sensing 17(2): 315-330.

Bryant, R.G., 1999. Application of AVHRR to monitoring a climatically sensitive playa. Case stuty: Chott El Djerid, Southern Tunisia. Earth Surface Processes and Landforms 24: 283-302.

Bryant, R.G. and Rainey, M.P., 2002. Investigation of flood inundation on playas within the zone of Chotts, using a time-series of AVHRR. Remote Sensing of Environment 82: 360-375.

Castañeda, C., 2002. El agua de las saladas de Monegros sur estudiada con datos de campo y de satélite. Consejo de Protección de la Naturaleza en Aragón, Zaragoza, 158 pp.

Castañeda, C., 2004. Las saladas del sur de Monegros: facies, régimen hídrico y estado actual. PhD Thesis. Universidad de Zaragoza, Spain, 2 volumes, 500 pp.

Castañeda, C. Herrero, J. and Casterad, A., 2004. La teledetección en la catalogación de las coberturas de las saladas de Monegros. Revista de la Asociación Española de Teledetección, 21: 29-34.

Collado, A.D., Chuvieco, E. and Camarasa, A., 2002. Satellite remote sensing analysis o monitor desertification processes in the crop-rangeland boundary of Argentina. Journal of Arid Environments 52: 121-133. 
Drake, N.A. and Bryant, R.G., 1994. Monitoring the flooding ratio of Tunisian playas using Advanced Very High Resolution Radiometer (AVHRR) imagery, in A.C.Millington and K. Pye (Eds.) Environmental Change in Drylands: Biogeographical and geomorphological perspectives. John Wiley \& Sons Ltd.

Faci, J.M., and Martínez-Cob, A., 1991. Cálculo de la evapotranspiración de referencia en Aragón. Diputación General de Aragón, pp 115.

García Vera, M.A., 1996. Hidrogeología de zonas endorreicas en climas semiáridos. Aplicación a los Monegros (Zaragoza y Huesca). Consejo de Protección de la Naturaleza en Aragón. Zaragoza. 297 pp.

Harris, A.R., 1994. Time series remote sensing of a climatically sensitive lake. Remote Sensing of Environment 50: 83-94.

Herrero, J. and Snyder, R.L., 1997. Aridity and irrigation in Aragón, Spain. Journal of Arid Environments 35: 55-547.

Hunt, E.R., Everitt, J.H., Ritchie, J.C., Moran, M.S., Booth, D.T., Anderson, G.L., Clark, P.E. and Seyfried, M.S., 2003. Applications and research using remote sensing for rangeland management. Photogrammetric Engineering and Remote Sensing 69(6): 675-693.

Laymon, C., Quattrochi, D., Malek, E., Hipps, L., Boettinger, J. and McCurdy, G., 1998. Remotely-sensed regional-scale evapotranspiration of a semi-arid Great Basin desert and its relationship to geomorphology, soils, and vegetation. Geomorphology 21: 329-349.

Malek, E., Biltoft, C., Klewicki, J. and Giles, B., 2002. Evaluation of annual radiation and windiness over a playa: possibility of harvesting the solar and wind energies. Journal of Arid Environments 52: 555-564. 
Nakayama, Y., Tanaka, S., Sugimura, T., and Endo, K., 1997. Analysis of hydrological changes in lakes of Asian arid zone by satellite data, in Earth Surface Remote Sensing (Cecchi, G., Engman, E.T. and Zilioli, E., editors). Proceedings of SPIEThe International Society for Optical Engineering, vol. 3222, Bellingham, Washington, pp. 201-210.

Pike, J.G., 1970. Evaporation of groundwater from coastal playas (sabkhah) in the Arabian Gulf. Journal of Hydrology 11: 79-88.

Prata, A.J., 1990. Satellite-derived evaporation from Lake Eyre, South Australia. International Journal of Remote Sensing 11(11): 2051-2068.

Rodó, X., Baert, E. and Comín, F.A., 1977. Variations in seasonal rainfall in Southern Europe during the present century: relationships with the North Atlantic Oscillation and the El Niño-Southern Oscillation. Climate Dynamics, 13: 275284.

Salvany, J.M., García Vera, M.A. and Samper, J., 1996. Geología e hidrogeología de la zona endorreica de Bujaraloz-Sástago. (Los Monegros, provincias de Zaragoza y Huesca). Acta Geológica Hispánica 30(4): 31-50.

Samper-Calvete, F.J., and García-Vera, M.A., 1998, Inverse modeling of groundwater flow in the semiarid evaporitic closed basin of Los Monegros, Spain. Hydrogeology Journal 6: 33-49.

Schneider, S.R., McGinnis, D.F., Jr. and Stephens,G., 1985. Monitoring Africa’s Lake Chad basin with Landsat and NOAA satellite data. International Journal of Remote Sensing 6(1): 59-73. 
Shaw, P.A. and Thomas, D.S.G., 1997. Pans, playas and salt lakes. Arid Zone Geomorphology: Process, Form and Change in Drylands, $2^{\text {nd }}$ edition. David S.G. Thomas Ed.

Valero-Garcés, B.L., Navas, A., Machín, J., Stevenson, T. And Davis, B., 2000. Responses of a saline lake ecosystem in a semiarid region to irrigation and climate variability. Ambio 29(6): 344-350.

Vazquez, P., Entraigas, I., Varni, M., Gandini, M and Usonoff, E., 2003. Identificación de patrones de anegamiento en la cuenca del arroyo del Azul, mediante el uso de imágenes Landsat. Revista de Teledetección 19: 43-49.

Yechieli, Y. and Wood, W.W., 2002. Hydrogeologic processes in saline systems: playas, sabkhas, and saline lakes. Earth-Science Reviews 58: 343-365. 